\title{
Influence of Mascarene High and Indian Ocean Dipole on East African Extreme Weather Events
}

\author{
Bob Alex Ogwang ${ }^{A, B}$, Victor Ongoma ${ }^{A, C *}$, Li Xing ${ }^{A}$, Faustin Katchele Ogou ${ }^{A}$ \\ Received: March 20, 2015 | Revised: May 8, 2015 | Accepted: June 15, 2015
}

\begin{abstract}
Extreme weather and climate events such as floods and droughts are common in East Africa, causing huge socio-economic losses. This study links the east African October-December (OND) rainfall, Indian Ocean Dipole (IOD) and Mascarene High (MH).Correlation analysis is applied to quantify the relationship between the index of IOD (Dipole Mode Index (DMI)) and OND rainfall. Results show that there exists a significant correlation between OND rainfall and DMI, with a correlation coefficient of o.6.During dry years, $\mathrm{MH}$ is observed to intensify and align itself in the southeast-northwest orientation, stretching up to the continent, which in turn inhibits the influx of moisture from Indian Ocean into East Africa. During wet years, $\mathrm{MH}$ weakens, shifts to the east and aligns itself in the zonal orientation. Moisture from Indian Ocean is freely transported into east Africa during wet years. Analysis of the drought and flood years with respect to the different variables including wind, velocity potential and divergence/ convergence revealed that the drought (flood) years were characterized by divergence (convergence) in the lower troposphere and convergence (divergence) at the upper level, implying sinking (rising) motion, especially over the western Indian Ocean and the study area. Convergence at low level gives rise to vertical stretching, whereas divergence results in vertical shrinking, which suppresses convection due to subsidence. Positive IOD (Negative IOD) event results into flood (drought) in the region. The evolution of these phenomena can thus be keenly observed for utilization in the update of seasonal forecasts.
\end{abstract}

Key words: Rainfall, Mascarene High, IOD, Drought, Flood, East Africa

\section{Introduction}

The East African region has always experienced extreme weather events which cause huge losses of life and property. It is therefore of great importance to have a good understanding of previous climate events and their impacts so as to make more accurate and reliable forecasts to minimize the impact of these extreme occurrences. The most important climate element in the tropics, where the domain of this study lies is rainfall (Shisanya, et al., 2011; Funk, Brown, 2009; Okoola, 1998; Ogwang, et al., 2014; Ongoma, 2013). This is because the economy of the countries in the Greater Horn of Africa (GHA) is mainly rely on rain fed agriculture. The economies are also driven mainly by hydropower which is equally affected by extreme weather events especially drought (Kaunda, 2012).

Three countries of the East African region (Kenya, Tanzania and Uganda) constituted the domain of this study. This domain is located within the latitudes $5^{\circ} \mathrm{N}$ and $12^{\circ} \mathrm{S}$ and longitudes $28^{\circ} \mathrm{E}$ and $42^{\circ} \mathrm{E}$ (Figure 1). The three countries share Lake Victoria; the largest lake in Africa.

Rainfall over East Africa exhibits a large spatial and temporal variability (Indeje, et al., 2001; Oettli, Camberlin, 2005; Mutai, et al., 1998). The spatial vari-

\footnotetext{
A Collaborative Innovation Center on Forecast and Evaluation of Meteorological Disasters/Key Laboratory of Meteorological Disaster, Ministry of Education, Nanjing University of Information Science and Technology, Nanjing 210044, P.R. China

B Uganda National Meteorological Authority, P.O. Box 7025, Kampala, Uganda

c South Eastern Kenya University, P.O. Box 170-90200, Kitui, Kenya

* Corresponding author: victor.ongoma@gmail.com
} 


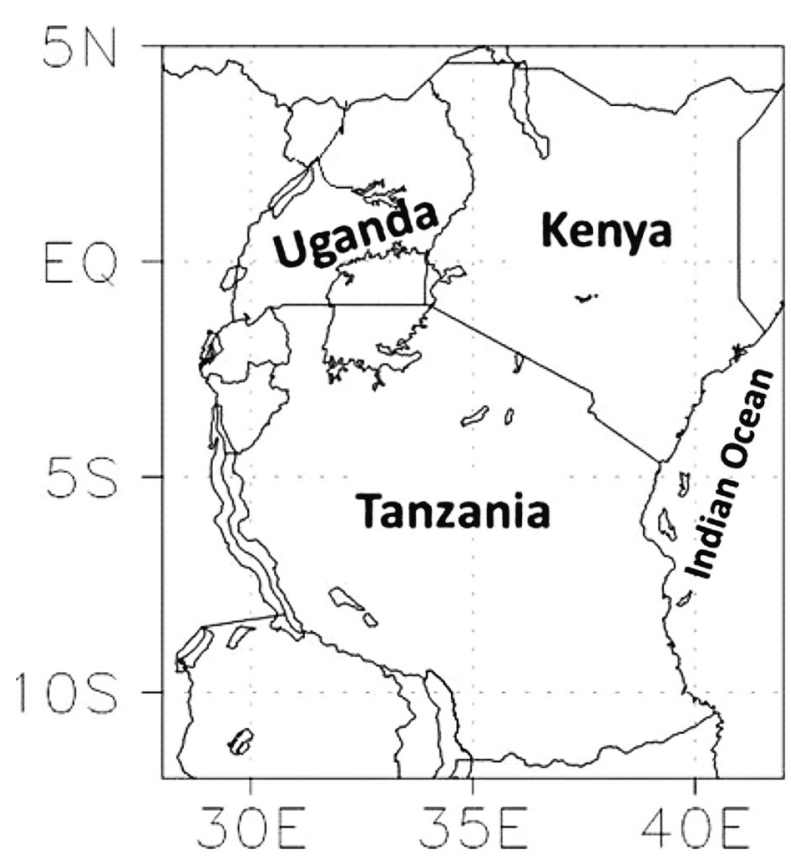

Figure 1. Map of East Africa

ation has been attributed to the existence of large scale systems and local systems such as inland water bodies which include Lake Victoria, Tanganyika and Kyoga, among others and a complex topography. The two main rainfall regimes experienced in the region are March-May (MAM) season; 'long rains' and October-December (OND); 'short rains' (Camberlin, Okoola, 2003; Owiti, Zhu, 2012; Okoola, 1996; Yang, et al., 2015). The two rain seasons coincide with the passage of the Inter Tropical Convergence Zone (ITCZ) over equator that lags behind the overhead sun by about a month, while the wet seasons are separated by two dry spells from June to August and January to February (Okoola, 1996; Mutemi, 2003). However, the annual cycle of rainfall in the southern parts of Tanzania becomes more unimodal with an austral summer maximum in southernmost areas (Ogallo, 1988). This is largely associated with the southern migration of the ITCZ across the western Indian Ocean into that region.

Many studies (e.g. Mutemi, 2003; Ogallo, 1988; Smith, Semazzi, 2014; Lyon, 2014; Bowden, Semazzi 2007; Shreck, Semazzi, 2004; Ropelewski, Halpert, 1987; Nicholson, 1996; Indeje, et al., 2000; Black, et al., 2013) have investigated and linked rainfall over east Africa with El Niño-Southern Oscillation (ENSO). Mutemi (2003) for instance observed a strong relationship between rainfall over east Africa and evolutionary phases of ENSO. The results showed that ENSO plays a significant role in determining the monthly and seasonal rainfall patterns in the East African region. In general, it is argued that floods are likely to occur in the region during El-Niño events and droughts tend to occur during La Nina events. Behera et al. (2005) noted that the Indian Ocean Dipole (IOD) has an overwhelming influence on the East African short rains (October to December) as compared to that of the ENSO. The IOD has two phases; positive and negative phases; the positive (negative) phase is associated with flood (drought) events in the region (Muhati, et al., 2007; Saji, et al., 1999).

The weather over East Africa is also influenced by the four high pressure systems: Mascarene, St. Hellena, Azores and Arabian Ridge (Manatsa, et al. 2014; Sun, et al., 1999). The weather systems have been widely used in short to extended - range forecasting (Sun, et al., 1999). However, the influence of these systems on seasonal and annual rainfall over East Africa has not been intensively investigated. A recent study by Manatsa et al. (2014) on impact of Mascarene High $(\mathrm{MH})$ variability on the East African 'short rains' established that droughts in East Africa are associated with a westward migration of the $\mathrm{MH}$ eastern ridge. However, the study pointed out that the relationship between $\mathrm{MH}$ and flood events and their link to an eastward migration of the $\mathrm{MH}$ is unclear.

The intensity of the ITCZ has a significant effect on the rainfall received in a given locality; it thus plays ITCZ plays a crucial part in the rainfall variability over East Africa (Black et al., 2003). This is a subject that has been ignored in many studies. According to Anyamba, Ogallo (1985), the position, and weakening and strengthening of ITCZ is to some extent influenced by the strength of southeasterly trade winds associated with the MH variability. The intensity of the south east (SE) trade winds thus provides a reasonable explanation to development of drought and floods in East Africa. The MH has great influence on the position of the meridional arm of the ITCZ, which is the main influence of rainfall seasonality over East Africa. According to Sun et al. (1999), the weakening of $\mathrm{MH}$ lead to the eastward shift of the meridional arms of the ITCZ, which is associated with wet years.

The primary motivation for undertaking this study is to investigate the effect of Mascarene High on of East Africa rainfall during the recent decades when the global warming signal has been rapidly intensifying. In order to understand the circulation patterns/ mechanisms, this study investigates the circulation patterns associated with wet (flood) and dry (drought) events, in regard to the linkage between wind anomalies over Indian Ocean and IOD events, and the influence of Mascarene high with respect to wet and dry events of rainfall over the region. The outcome of this research will help in improving the accuracy and timeliness of the weather forecast in the region, this is key for socio-economic development. 


\section{Data and methods}

\section{Data}

The availability of long-time climate data over east Africa, like the rest of Africa continues to experience some difficulties (Camberlin, Philippon, 2002). More so, the available data are also riddled with numerous gaps in both space and time (Shreck, Semazzi, 2004). These limitations in the quantity and quality of in situ observations impose substantial constraints on diagnostic studies of the regional climate (rainfall) variability (Owiti, Zhu, 2012). Proxy rainfall datasets have therefore been used in the region in studies where spatial resolution and study period are of importance.

In this study, the precipitation (rainfall) dataset (1950 - 2010) used is the Global Precipitation Climatology Centre (GPCC) monthly precipitation dataset provided from 1901-present. It is calculated from the global station data (Schneider et al., 2013). GPCC Precipitation data is provided by the NOAA/OAR/ESRL PSD, Boulder, Colorado, USA, from their Web site at http://www.esrl.noaa.gov/psd/ .

The SST data (1950 - 2010) used is the Extended Reconstructed Sea Surface Temperature (ERSST) versionzb from the National Oceanic and Atmospheric Administration/National Climatic Data Center (Smith et al., 2008), available in their website at http:// iridl.ldeo.columbia.edu/SOURCES/.NOAA/.NCDC/. ERSST/.version3b/.sst/.

Reanalysis fields from the National Center for Environmental Prediction/National Center for Atmospheric Research (NCEP/NCAR) (Kalnay et al., 1996), including zonal and meridional wind and geopotential height, with a horizontal resolution of $2.5^{\circ} \times 2.5^{\circ}$ were also used.

The Dipole Mode Index (DMI) is an index used to quantify Indian Ocean Dipole (IOD) is used in this study, it has by been used by a number of studies (e.g. Behera et al., 2005; Muhati et al., 2007; Saji et al., 1999). The intensity of the IOD is given by anomalous SST gradient between the western equatorial Indian Ocean $\left(50^{\circ} \mathrm{E}-70^{\circ} \mathrm{E}\right.$ and $\left.10^{\circ} \mathrm{S}-10^{\circ} \mathrm{N}\right)$ and the south eastern equatorial Indian Ocean $\left(90^{\circ} \mathrm{E}-110^{\circ} \mathrm{E}\right.$ and $10^{\circ} \mathrm{S}$ $0^{\circ} \mathrm{N}$ ). When the DMI is positive, the phenomenon is known as the positive IOD event and when it is negative, it is referred to as negative IOD event. The DMI used in this study is the seasonal average from June till November for the period 1958 to 2006, normalized by the standard deviation of the DMI (available online at http://www.jamstec.go.jp/frcgc/research/d1/ iod/HTML/Dipole\%2oMode\%2oIndex.html).

\section{Methods}

Composite analysis involves identifying and averaging one or more categories of fields of a variable select- ed according to their association with key conditions. Results of the composites are then used to generate hypotheses for patterns which may be associated with the individual scenarios (Folland, 1983). In this study, the key conditions for the composite analysis are wet/ flood and dry/drought events, where the composites for wet and dry years were separately done, especially for wind, geopotential height, velocity potential/divergence, and SST. This is mainly to detect the circulation anomalies associated with wet/dry events. A number of authors have used composite methods in their analyses over the east African region (Okoola, 1999; Ininda, 1995; Ogwang, et al., 2012).

Simple Correlation analysis reveals simple relationship between pairs of variables (Wilks, 2006). In this study, correlation analysis is aimed at quantifying/displaying the relationship between DMI and OND rainfall over east Africa. Schreck, Semazzi (2004) found that the second most significant OND regional precipitation EOF mode was significant over this region. The mode is characterized by decadal variability and a dipole rainfall loading pattern.

\section{Results and discussion}

Figure 2 presents interannual variability of OND spatially-averaged rainfall anomalies (rainfall index (RF)); and DMI for 1958 - 2006. The amplitude of variability of RF is generally higher than DMI over the study period. The years 1951, 1961, 1982, 1997, and 2006 were identified as wet years while 1998 and 2005 were considered dry years (Figure 2). The identification of dry and wet years was based on the interannual standardized rainfall anomaly; +1 and -1 for wet and dry years respectively. The categorization of above and below normal years employed herein is similar to the approach used by Zhi (2001) and Tan et al. (2014). The years 1997 and 2005 are the most pronounced years as the wet and dry years respectively in the recent past.

DMI generally exhibits a significant positive correlation with both the rainfall index (RF) and the spatial rainfall over east Africa (Figure 7).

Analysis of the geopotential height at $850 \mathrm{hpa}$ to depict the behavior of Mascarene subtropical High (Mascarene High), where 1530 gpm contour is chosen and its behavior examined during wet and dry years. Results show that during dry years (Figure 3b), Mascarene High intensifies and aligns itself in the southeast - northwest orientation, stretching up to the continent (reaching about $30^{\circ} \mathrm{E}$, with the center around $70^{\circ} \mathrm{E}, 30^{\circ} \mathrm{S}$, at $1560 \mathrm{gpm}$ ), which in turn inhibits the influx of moisture from Indian Ocean into east Africa by influencing the air flow. During wet years (Figure 3a), Mascarene High weakens (withdraws up to about $45^{\circ} \mathrm{E}$, with the center around $80^{\circ} \mathrm{E}, 25^{\circ} \mathrm{S}$ at 1550 


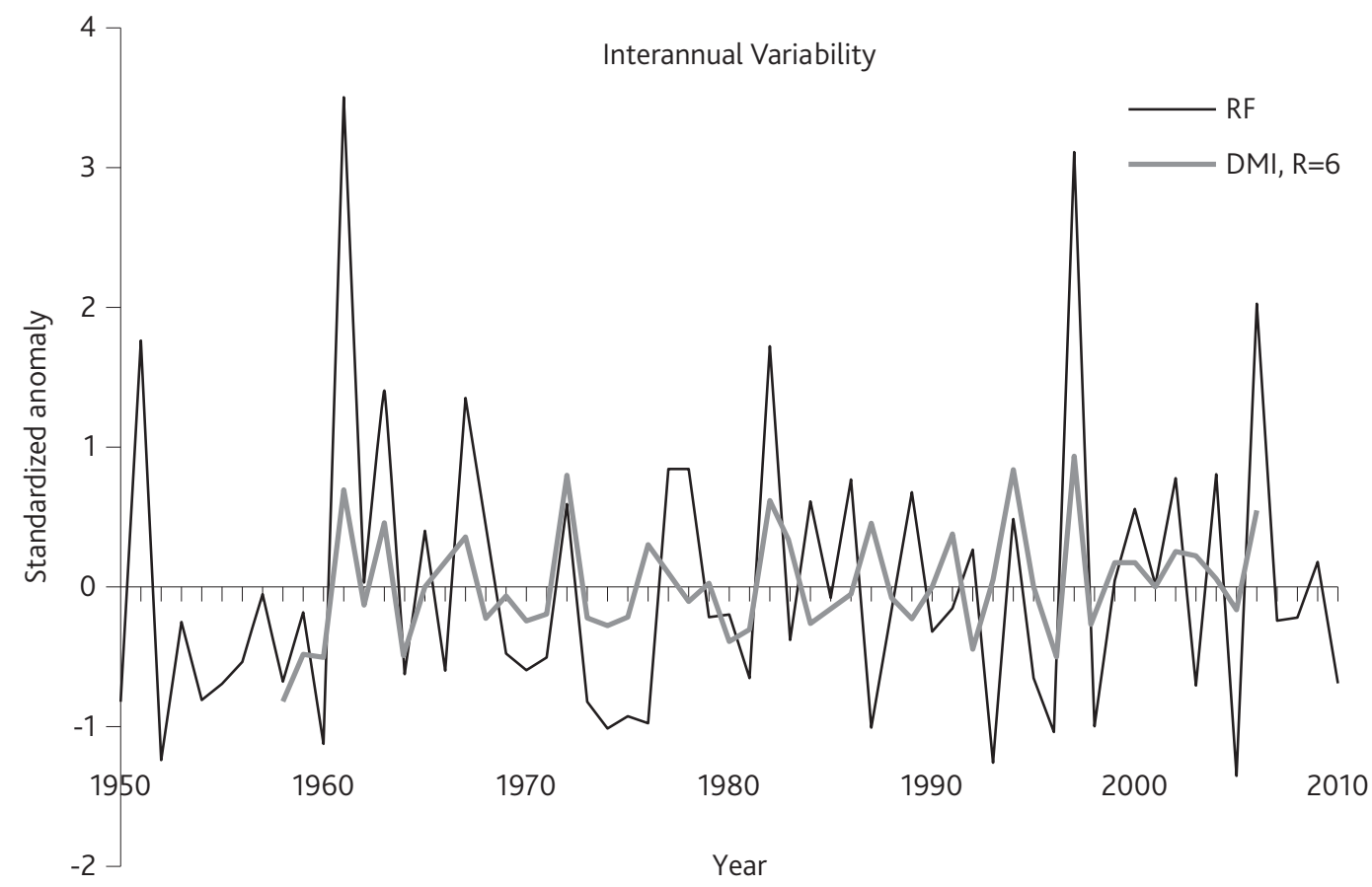

Figure 2. Inter-annual variability of the east African OND rainfall index (RF) for the period 19502010 (based on GPCC data), and DMI (1958-2006). Datasets are standardized using their respective standard deviations. A significant correlation coefficient of 0.6 at $99 \%$ level of significance is observed

gpm) and aligns itself in the zonal orientation. Moisture from Indian Ocean is freely transported (by easterly winds) into East Africa during wet years.

Figure 4 shows composite mean anomaly of velocity potential and divergent/convergent winds in the lower (850 hpa) and upper (200 hpa) levels over east Africa and western Indian Ocean during wet and dry years. During wet years, there is convergence at low levels and divergence at the upper levels (Figure 4a, c). The contrary is observed in the dry years, where convergence occurs in the upper level and divergence in the lower level (Figure $4 \mathrm{~b}, \mathrm{~d}$ ). Convergence at low level gives rise to vertical stretching, whereas divergence results in vertical shrinking, which sup-

(a)

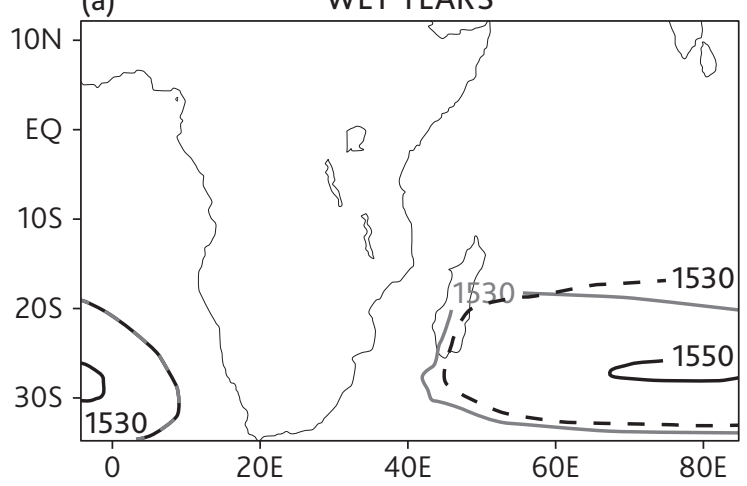

presses convection due to subsidence (Barry, Chorley, 2003).

In order to understand the prevailing circulation patterns and SST anomaly over the Indian Ocean during IOD events, the wind (superimposed on SST) patterns at 1000 hpa is examined. The climatology of OND winds along equator (between longitudes $60^{\circ} \mathrm{E}-100^{\circ} \mathrm{E}$, dotted line) over Indian Ocean is characterized by westerly flow. This flow is noted to be reversed during positive IOD events (Figure $5 \mathrm{c}$ ). During dry years (Figure $5 \mathrm{~b}$ ), the westerly flow in the central equatorial Indian Ocean is enhanced towards the maritime continent (between longitudes $80^{\circ} \mathrm{E}$ and $100^{\circ} \mathrm{E}$ ). During a positive IOD event, there exists an anomalous warm pool over

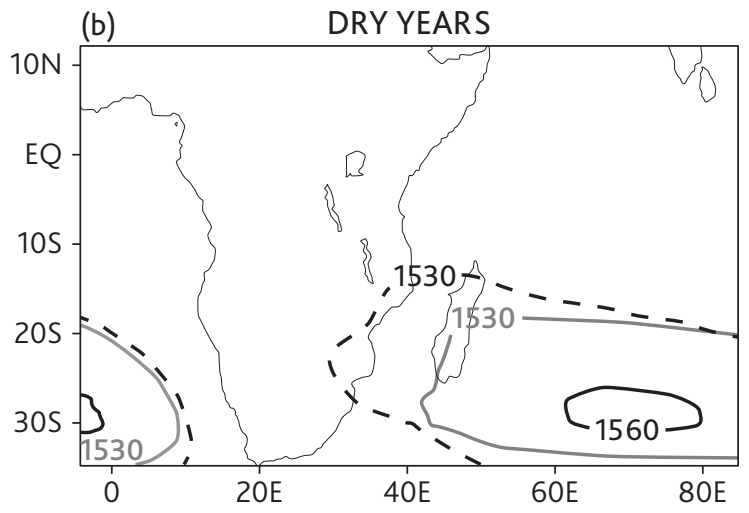

Figure 3. Composite mean geopotential height at 850 hpa depicting Mascarene High during (a) wet years (1951, 1961, 1982,1997 , and 2006) (b) dry years (1998 and 2005). Climatology of 1530 gpm (red) and its behavior during drought and flood events are shown with dotted-black lines 

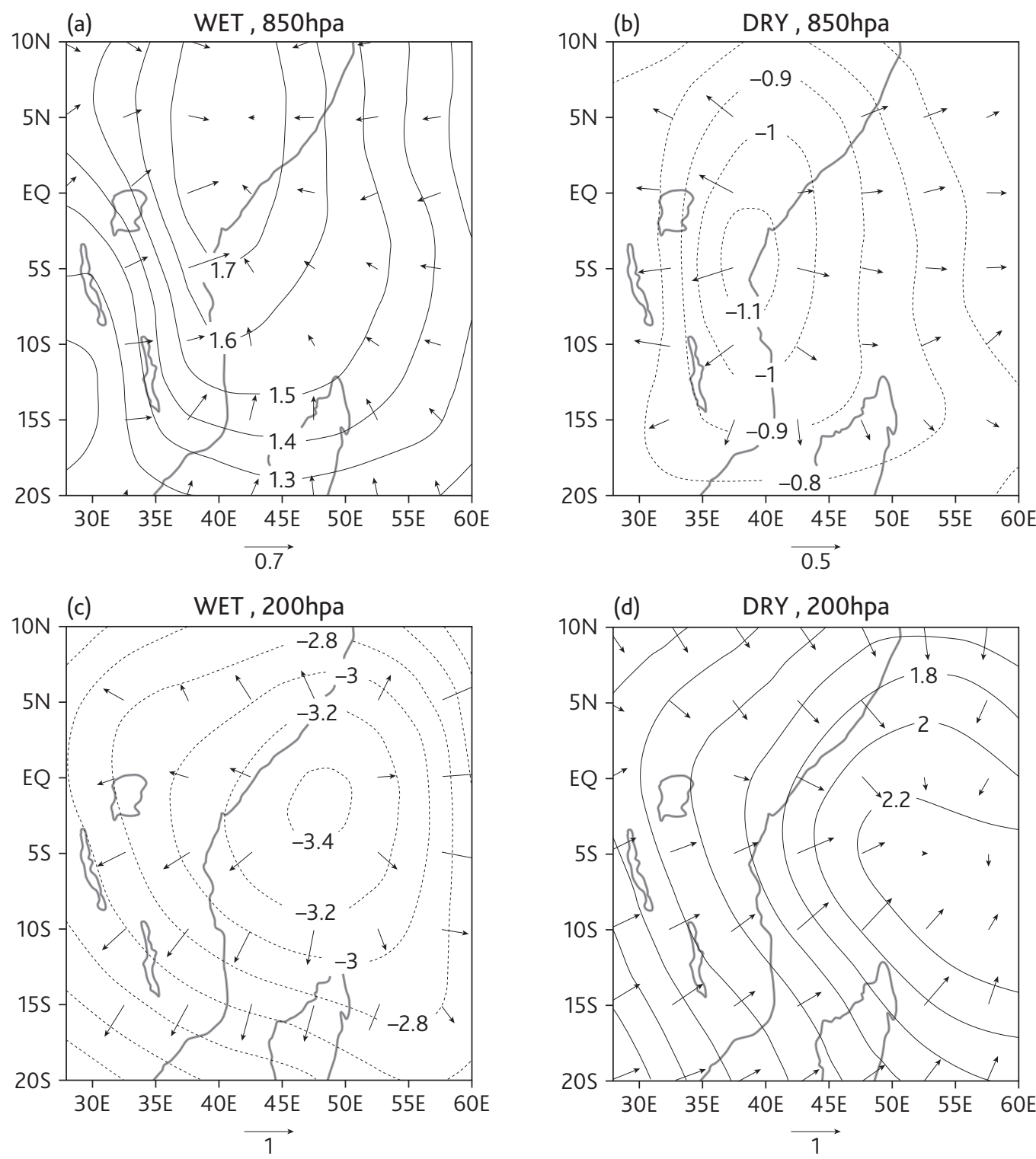

Figure 4. Composite mean anomaly of velocity potential $\left(\times 10^{6} \mathrm{~m}^{2} \mathrm{~s}^{-1}\right) /$ divergent (convergent) winds at $850 \mathrm{hpa} \mathrm{(a)} \mathrm{wet} \mathrm{years} \mathrm{(b)} \mathrm{dry} \mathrm{years,} \mathrm{and} \mathrm{at} \mathrm{200hpa} \mathrm{(c)} \mathrm{wet} \mathrm{years} \mathrm{(d)} \mathrm{dry} \mathrm{years.} \mathrm{Contours} \mathrm{represent}$ velocity potential and are at $0.1 \times 10^{6} \mathrm{~m}^{2} \mathrm{~s}^{-1}$ intervals (for $850 \mathrm{hpa}$ ) and $0.2 \times 10^{6} \mathrm{~m}^{2} \mathrm{~s}^{-1}$ (for $200 \mathrm{hpa}$ ). Vectors show wind divergence/convergence

the western Indian Ocean and an anomalous cold pool over the south eastern zone. The warm and cold pools are reversed during the negative IOD events.

Further analysis of the annual cycle of rainfall under three cases (i.e. Positive IOD years $\left(\mathrm{IOD}^{*}\right)$, years immediately after positive IOD years (IOD+1) and the long term mean (LTM)), focusing on OND season reveals that higher rainfall amounts are recorded during positive IOD years than the climatology of OND rainfall over the region. Years after positive IOD events generally experience less OND rainfall compared to the LTM (Figure 6, Table 1). The annual rainfall variation with variation in IOD is highest in the OND sea- son as compared to the MAM season. This is in consistency with earlier studies (e.g. Mutai, Ward, 2000; Nicholson, 2004).

Table 1. The mean OND rainfall (RF), averaged over east Africa $\left[28^{\circ} \mathrm{E}-42^{\circ} \mathrm{E}, 12^{\circ} \mathrm{S}-5^{\circ} \mathrm{N}\right]$, showing three categories; the long term mean (LTM) based on 1971-2000, IOD*, and IOD+1 (defined earlier). RID denotes rainfall increase or decrease

\begin{tabular}{|l|c|c|}
\hline & $\mathrm{RF}(\mathrm{mm})$ & $\mathrm{RID}(\mathrm{mm})$ \\
\hline LTM & 94.5 & \\
\hline IOD* & 149.1 & 54.6 \\
\hline IOD+1 & 75.3 & -19.2 \\
\hline
\end{tabular}


(a) OND wind/SST LTM
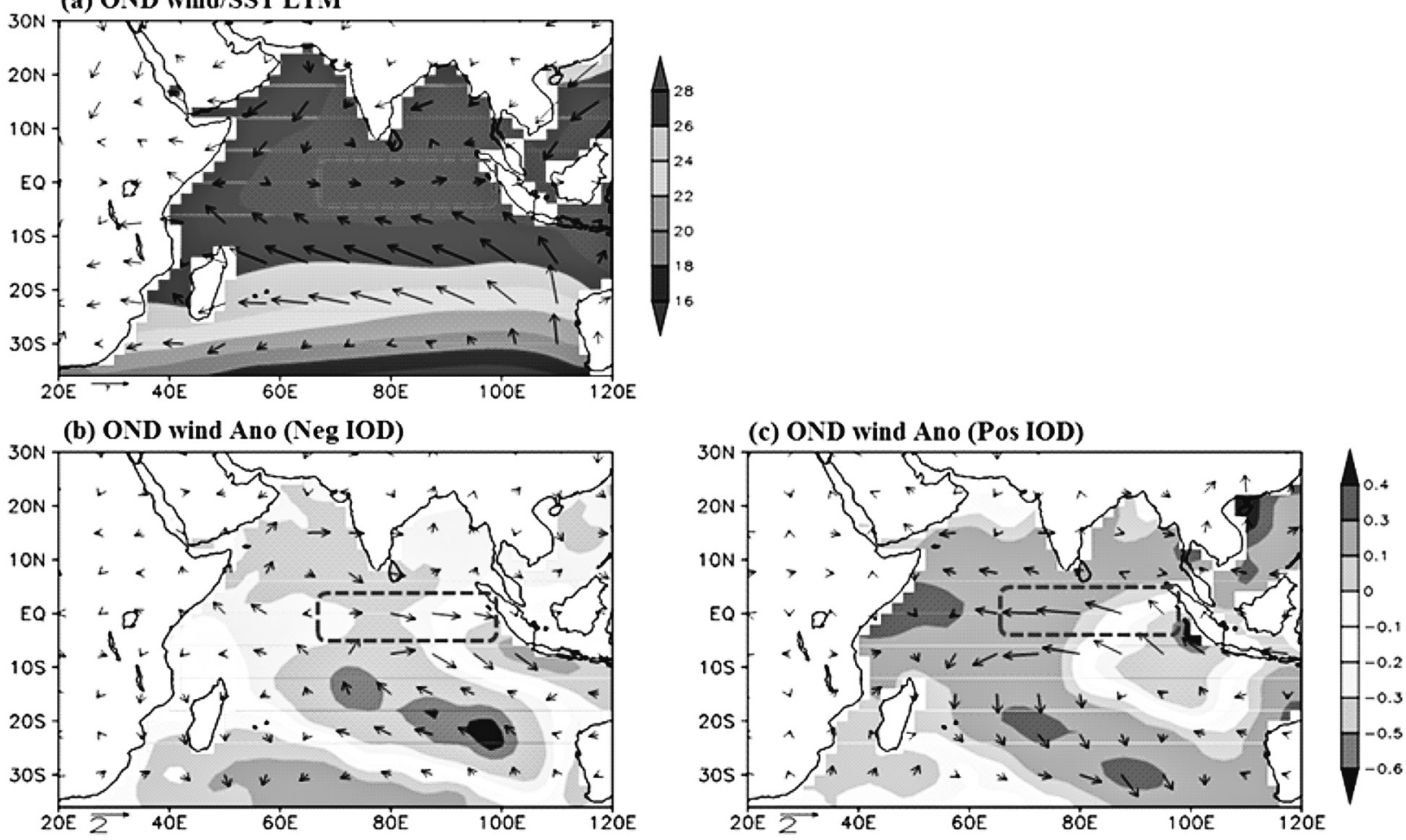

Figure 5. (a) OND climatology of surface wind (vector) and sea surface temperature (SST, shaded)over Indian Ocean (b) Composite mean anomaly of OND surface wind/SST during years of negative events of IOD $(1958,1974,1975,1992)$, and (c) same as (b) but for positive events of IOD (1961, 1972, 1994, 1997)

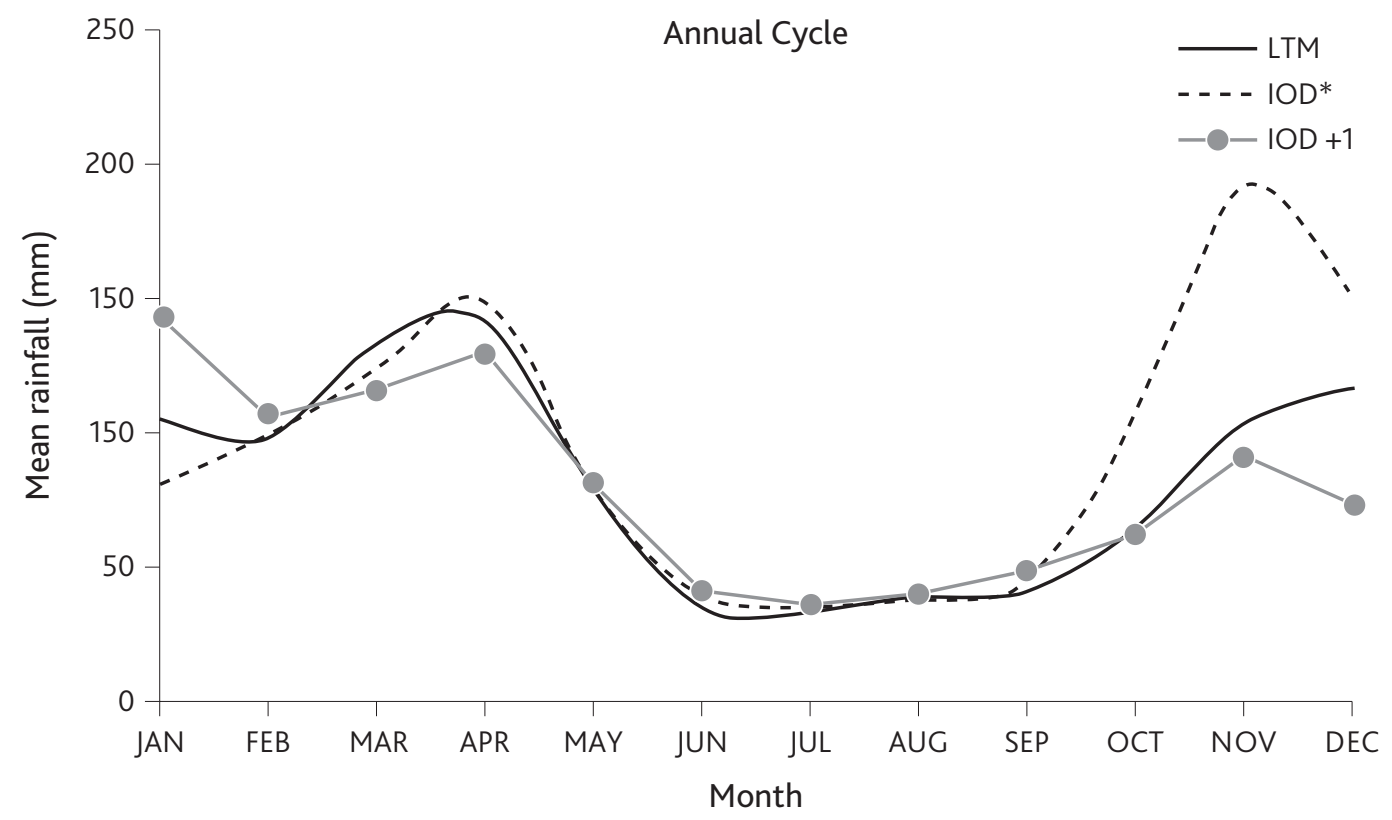

Figure 6. The annual cycle of rainfall used to examine the October to December (OND) rainfall over east Africa under three cases (Positive IOD years (1961, 1967, 1972, 1982, and 1997), denoted by IOD*, years immediately after positive IOD events $(1962,1968,1973,1983$, and 1998), denoted by IOD+1, and the long term mean (LTM)) 


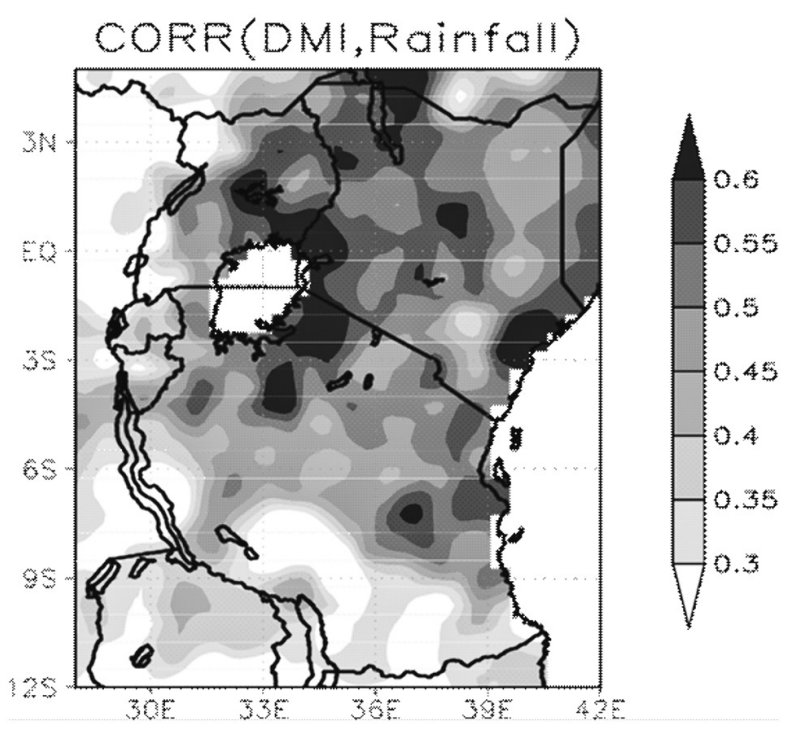

Figure 7. Spatial correlation map between DMI and east African OND rainfall. The shaded area is significant at 99\% confidence level

\section{Conclusion}

The east African region generally experiences a bimodal rainfall regime. The most common extreme weather events in the region are floods and drought. The amplitude variability of RFI is generally higher than DMI over the study period, with a significant correlation coefficient of 0.6 between the two.

$\mathrm{MH}$ and IOD greatly influence the east African extreme weather events.MH is observed to intensify and align itself in the southeast - northwest orientation, stretching up to the continent, which in turn inhibits the influx of moisture from Indian Ocean into east Africa. During wet years, MH weakens, its pressure centre shifts to the east and it aligns itself in the zonal orientation. Moisture from Indian Ocean is freely transported into east Africa during wet years. During dry years, $\mathrm{MH}$ is observed to intensify and align itself in the southeast - northwest orientation, stretching up to the continent, which in turn inhibits the influx of moisture from Indian Ocean into east Africa.

Analysis of the drought and flood years with respect to the different variables including wind, velocity potential and divergence/convergence vectors revealed that the drought (flood) years were characterized by divergence (convergence) in the lower troposphere and convergence (divergence) at the upper level, implying sinking (rising) motion, especially over the western Indian Ocean and the study area. Convergence at low level gives rise to vertical stretching, whereas divergence results in vertical shrinking, which suppresses convection due to subsidence (Barry, Chorley, 2003).

Positive IOD (Negative IOD) event results into flood (drought) in the region. The evolution of these phenomena can thus be keenly observed and applied in seasonal forecasting to avert the huge losses associated with extreme weather events.

During wet years, the wind circulation is observed to converge in the low levels over the western Indian Ocean and diverge in the upper levels, the opposite is observed in dry years. The IOD is observed to be positive during wet years and negative during dry years. The development and evolution of these phenomena can be therefore be closely monitored in the update of seasonal forecasts.

\section{Acknowledgments}

Authors express their gratitude to NOAA for provision of the datasets used in this study. Special appreciation goes to Chinese Scholarship Council (CSC) for the financial support, and Nanjing University of Information Science and Technology for providing the required facilities for data analysis and for all other forms of support.

\section{References}

Barry, R.G Chorley, R.J. 2003. Atmosphere, weather and climate. $8^{\text {th }}$ edn. London, Routledge.

Behera, S.K., Luo, J.J., Masson, S., Delecluse, P., Gualdi, S., Navarra, A., Yamagata, T. 2005. Paramount Impact of the Indian Ocean Dipole on the East African Short Rains: A CGCM Study. Journal of Climate 18, 4514-4530

Black, E, Slingo, J.M., Sperber, K.R. 2003. An observational study of the relationship between excessively strong short rains in coastal East Africa and Indian Ocean SST. Monthly Weather Review 131, 74-94.

Bowden, J.H., Semazzi, F.H.M. 2007. Empirical analysis of intraseasonal climate variability over the Greater Horn of Africa. Journal of Climate 20, 57155731

Camberlin, P., Okoola, R.E. 2003. The onset and cessation of the 'long rains' in eastern Africa and their interannual variability. Theoretical Applied Climatology 75, 43-54

Camberlin, P., Philippon, N. 2002. The East African March-May rainy season: Associated atmospheric dynamics and predictability over the 1968-1997 period. Journal of Climate 15, 1002-1019

Folland, C.K. 1983. Regional-Scale Interannual variability of climate. A north-west European perspective. Meteorological Magazine 12, 163-187

Funk, C., Brown, M.E. 2009. Declining global per capita agricultural production and warming oceans threaten food security. Food Security 1, 271-289.

Indeje, M., Semazzi, F.H.M., Ogallo, L.J. 20oo. ENSO signals in East African rainfall seasons. International Journal of Climatology, 20, 19-46 
Indeje, M, Semazzi, F.H.M., Xie, L., Ogallo, L.J. 2001. Mechanistic model simulations of the East African Climate using NCAR Regional Climate Model: Influence of large scale orography on the Turkana Low-Level Jet. Journal of Climate 14, 2710 -2724.

Ininda, J.M. 1995. Numerical simulation of the influence of sea surface temperature anomalies on the East African seasonal rainfall. PhD. Thesis, University of Nairobi, Kenya

Kalnay, E., Kanamitsu, M., Kistler, R., Collins, W., Deaven, D., Gandin, L., Iredel, L., Saha, H., White, G., Woolle, J., Zhu, Y., Chelliah, M., Ebisuzaki, W., Higgins, W., Jonawiak, J., Mo, C.K., Ropelewski, C., Wang, J., Leetmaa, A., Reynolds, R., Jenne, R., Joseph, D. 1996. The NCEP/NCAR 40-Year Reanalysis Project. Bulletin of American Meteorological Society $77,437-471$

Kaunda, C.S., Kimambo, C.Z., Nielsen, T.K. 2012. Potential of small-scale hydropower for electricity generation in sub-Saharan Africa. Renewable Energy. doi:10.5402/2012/132606.

Lyon, B. 2014. Seasonal Drought in the Greater Horn of Africa and Its Recent Increase during the March

- May Long Rains. Journal of Climate 27, 7953 - 7975

Manatsa, D., Morioka, Y., Behera, S.K., Matarira, C.H., Yamagata, T. 2014. Impact of Mascarene High variability on the East African 'short rains'. Climate Dynamics 42, 1259 - 1274. DOI 10.1007/soo382-0131848-z

Muhati, F.D., Ininda, J.M., Opijah, F.J. 2007. Relationship between ENSO parameters and the trends and periodic fluctuations in east African rainfall. Journal of Kenya Meteorological Society 1, 20 - 43.

Mutai, C., Ward, M.N., Coleman, A.W. 1998. Towards the prediction of the East Africa short rains based on sea-surface temperature-atmosphere coupling. International Journal of Climatology 18, 975-997

Mutai, C.C., Ward, M.N. 200o. East African rainfall and the tropical circulation/convection on intraseasonal to interannual timescales. Journal of Climate $13,3915-3939$

Mutemi, J.N. 2003. Climate anomalies over eastern Africa associated with various ENSO evolution phases: PhD. Thesis, University of Nairobi, Kenya

Nicholson, S.E. 1996. A review of climate dynamics and climate variability in eastern Africa. In: Johnson, T.C., Odada, E. Eds., The Limnology, Climatology and Paleoclimatology of the East African Lakes, pp. 25-56. Gordon \& Breach

Nicholson, S.E. 200o. The nature of rainfall variability over Africa on timescales of decades to millennia. Global Planetary Change 26, 137-158

Oettli, P., Camberlin, P. 2005. Influence of topography on monthly rainfall distribution over East Africa. Climate Research 28, $199-212$
Ogallo, L.J. 1988. Relationships between seasonal rainfall in East Africa and southern oscillation. Journal of Climatology 8, 31-43

Ogwang, B.A., Guirong, T., Haishan, C. 2012. Diagnosis of September - November Drought and the Associated Circulation Anomalies Over Uganda. $\mathrm{Pa}$ kistan Journal of Meteorology 9,11-24

Ogwang, B.A., Chen, H., Li, X., Gao, C. 2014. The influence of Topography on East African October to December climate: Sensitivity experiments with RegCM4. Advances in Meteorology. Doi:10.1155/2014/143917.

Okoola, R.E. 1996. Space-Time Characteristics of ITCZ over Equatorial East Africa during anomalous rainfall years. PhD. Thesis, University of Nairobi, Kenya

Okoola, R.E. 1998. Spatial evolutions of the active convective patterns across the Equatorial East Africa region during northern hemisphere spring season using outgoing longwave radiation records. Meteorology and Atmospheric Physics 66, 51-63

Okoola, R.E. 1999. A diagnostic study of the East African monsoon circulation during the northern hemisphere spring season. International Journal of Climatology 19, 143-169

Owiti, Z., Zhu, W. 2012. Spatial distribution of rainfall seasonality over East Africa. Journal of Geography and Regional Planning 5-15, 409-421

Ongoma, V. 2013. A review on the Effects of Climate Change on occurrence of Aflatoxin and its impacts on Food Security in Semi-Arid Areas of Kenya. International Journal of Agricultural Science Research 2, 307-311

Ropelewski, C.F., Halpert, M.S. 1987. Global and regional scale precipitation patterns associated with the El Nino/ Southern Oscillation. Monthly Weather Review 115, 1606-1626

Saji, N.H., Goswani, B.N., Vinayachandran, P.N., Yamagata, T. 1999. A dipole mode in the tropical Indian Ocean. Nature 401, 360-363

Schneider, U., Becker, A., Finger, P., Meyer-Christoffer, A., Ziese, M., Rudolf, B. 2013. GPCC's new land surface precipitation climatology based on qualitycontrolled in situ data and its role in quantifying the global water cycle. Theoretical and Applied Climatology 115, 15-40

Schreck, C.J., Semazzi, F.H.M. 2004. Variability of the recent climate of eastern Africa. International Journal of Climatology 24, 681-701

Shisanya, C.A., Recha, C., Anyamba, A. 2011. Rainfall Variability and Its Impact on Normalized Difference Vegetation Index in Arid and Semi-Arid Lands of Kenya. International Journal of Geosciences, 2, 36-47. 
Smith, K.A., Semazzi, F.H.M. 2014. The Role of the Dominant Modes of Precipitation Variability over Eastern Africa in Modulating the Hydrology of Lake Victoria. Advances in Meteorology. Doi. org/10.1155/2014/516762

Smith, T.M., Reynolds, R.W., Peterson, T.C., Lawrimore, J. 2008. Improvements to NOA A's Historical Merged Land-Ocean Surface Temperature Analysis (1880-2006). Journal of Climate 21, 2283-2296

Sun, L., Semazzi, F.H.M, Giorgi, F., Ogallo, L. 1999. Application of the NCAR Regional Climate Model to eastern Africa 2. Simulation of interannual variability of short rains. Journal of Geophysical Research 104, D6, 6549-6562. Doi: 0148-0227/99/1998 JD200050509.00
Tan, G.R, Li, H., Ren, H.L., Chen, H. 2014. Quantifying synoptic eddy feedback onto the low-frequency flow associated with anomalous temperature events in January over China. International Journal of Climatology. DOI: 10.1002/joc.4135

Wilks, S.D. 2006. Statistical Methods in the Atmospheric Sciences. $2^{\text {nd }}$ Edn, Academic Press, San Diego.

Yang, W, Seager R, Cane M.A., Lyon B. 2015. The Annual Cycle of East African Precipitation. Journal of Climate 28, 2385-2404. DOI: 10.1175/JCLI-D-14-00484.1

Zhi, X.F. 2001. Interannual variability of the Indian summer monsoon and its modeling with zonally symmetric 2D-Model. Shaker Verlag, 151 pp 